\title{
Production of enterotoxin and cytotoxin in Campylobacter jejuni strains isolated in Costa Rica
}

\author{
INGER FLORIN and FLORENCIA ANTILLON*
}

Department of Bacteriology, Karolinska Institute, S-104 01 Stockholm, Sweden and "Department of Microbiology, Faculty of Microbiology, University of Costa Rica, San José, Costa Rica

\begin{abstract}
Summary. The production of toxins by 79 strains of Campylobacter jejuni isolated in Costa Rica from children with compylobacter-induced diarrhoea (44 strains) and from chickens (35 strains) was studied. An enterotoxic effect giving a rounding of mouse adrenocortical tumour (Y1) cells, which could be neutralised with antitoxin against Escherichia coli heat-labile enterotoxin, was detected in supernates from $16(62 \%)$ of 26 strains from children with watery diarrhoea, in $5(28 \%)$ of 18 strains from children with bloody or inflammatory diarrhoea, and in $12(34 \%)$ of the 35 strains from chickens. Cytotoxic effects in human lung fibroblasts (MRC-5), African Green monkey kidney (Vero) cells and human cervical carcinoma (HeLa) cells were observed in none of the 26 strains from children with watery diarrhoea, in $2(11 \%)$ of the 18 strains from children with bloody or inflammatory diarrhoea, and in $6(17 \%)$ of the 35 strains from chickens. The simultaneous production of enterotoxin and cytotoxin was detected in four strains. The cytotoxic effect, which was most prominent in cells freshly seeded at a low density, appeared as a lethal rounding of the cells. Fibroblasts were more sensitive than epithelial cells. The effects of the supernates were inactivated by heating at $100^{\circ} \mathrm{C}$ for $10 \mathrm{~min}$ and decreased after 1 week at $4{ }^{\circ} \mathrm{C}$. The production of toxins was lost after storage of the strains for one year at $-70^{\circ} \mathrm{C}$.
\end{abstract}

\section{Introduction}

During the last decade, Campylobacter spp. have been recognised as the third most common cause of acute diarrhoea or enteritis in children, both in the industrialised world and in developing countries. ${ }^{1}$ This is true in Costa Rica, where the frequency of campylobacter infections is $c .8 \%$ of all enteric infections. ${ }^{2}$ The epidemiology of this disease in Costa Rica has been studied in only one report. ${ }^{3}$

Potentially pathogenic properties of Campylobacter spp. include adhesion to the intestinal mucosa, invasion of intestinal epithelial cells and production of toxins. ${ }^{1}$ The production of an enterotoxin and (at least) three different cytotoxic effects on eukaryotic cells have been reported. The enterotoxin causes fluid accumulation in animal intestinal loops as well as rounding of mouse adrenocortical ( $\mathrm{Y} 1)$ cells and elongation of chinese hamster ovary $(\mathrm{CHO})$ cells. $^{1}$ These effects of the campylobacter enterotoxin can be neutralised by antitoxin raised against cholera toxin or Escherichia coli heat-labile enterotoxin (LT). ${ }^{1}$ The effects are caused by an increase in the intracellular level of cyclic AMP, probably in a similar way as for cholera toxin and Escherichia coli LT. The campylobacter enterotoxin has been purified by affinity

Received 6 June 1991; accepted 4 Sept. 1991. chromatography and partially characterised. It has a mol. wt of c. $70 \mathrm{kDa}$ with two subunits of 60 and $15 \mathrm{kDa}^{4-10}$

It is impossible to deduce from published reports how many cytotoxins have been detected, because authors have used different cell types to detect cytotoxic effects, and only one group has purified their cytotoxin. A cytotoxic effect was first detected in $\mathrm{HeLa}$ (human cervical carcinoma), HEp-2 (human laryngeal carcinoma), MRC-5 (human diploid lung fibroblasts) and $\mathrm{CHO}$ cells but not in Vero (African Green monkey kidney) cells ${ }^{11}$ and was later found to be correlated with ${ }^{51} \mathrm{Cr}$-release from exposed cells. ${ }^{12} \mathrm{~A}$ cytotoxic effect with the same activity spectrum against different cell types was later detected by another group. ${ }^{13}$ Two additional reports probably deal with the same cytotoxic effect, since there was no effect in Vero cells, although among the other cells mentioned above, only $\mathrm{CHO}$ or HeLa cells, or both, were tested and found to be sensitive. ${ }^{14,15}$ The toxin studied in these reports was not neutralised by antitoxin against Shiga-toxin. The mol. wt was $50-70 \mathrm{kDa}^{15}$ Mahajan and Rodgers ${ }^{16}$ assumed that they worked with the same toxin, but their toxin was tested only in human intestinal cells, chicken embryo fibroblasts and CHO cells. This cytotoxin, of mol. wt $68 \mathrm{kDa}$, was recently purified to homogeneity and characterised biochemically. ${ }^{16}$

A second cytotoxic effect in HeLa and Vero cells 
was later detected. ${ }^{17,18}$ Toxic effects in HeLa and Vero cells, ${ }^{19,20}$ and in HeLa cells (neutralised with antitoxin against Shiga-toxin), ${ }^{21}$ reported by other groups, are probably identical with this one. This second cytotoxic effect may be the campylobacter analogue of the Shiga-like toxin (verotoxin), active on Vero cells, produced by $E$. coli ${ }^{22}$ although the cytotoxic effect on Vero cells first referred to ${ }^{18}$ could not be neutralised with antitoxin against $E$. coli verotoxin. In some other reports, only $\mathrm{HeLa}$ or $\mathrm{CHO}$ cells, or both, were tested $^{23,24}$ These cytotoxic effects could thus be identical with either the first (non-Vero) or the second (Vero-) cytotoxic effect.

A third cytotoxin, clearly distinct from the two above and termed cytolethal distending toxin (CLDT), induced a slowly developing distention of HeLa, Vero and $\mathrm{CHO}$ cells but had no effect in Y1 cells. ${ }^{25}$ The modes of action behind all these cytotoxic effects have been studied only briefly. ${ }^{12}$

The aims of this project were to determine the frequency of production of enterotoxin and cytotoxin(s) in strains of $C$. jejuni isolated in Costa Rica, to isolate cytotoxin-producing strains and to characterise the cytotoxin(s) further.

\section{Materials and methods}

\section{Bacterial isolates}

Strains of C. jejuni (total 79) were collected in Costa Rica from children under 2 years old with campylobacter-induced diarrhoea (44 strains) and from chickens ( 35 strains). The strains of human origin were isolated and kindly provided by Dr Mata, Instituto de Investigaciones en Salud, San José, Costa Rica;,26 of these strains were from children with watery diarrhoea and 18 from children with bloody or inflammatory diarrhoea (leucocytes and blood detected by microscopy). The strains from chickens were isolated as previously described ${ }^{26}$ from refrigerated chickens obtained from local stores; the chickens had been bred at several family farms. All strains were confirmed as C. jejuni by standard biochemical tests (Gram's stain, motility, production of oxidase and catalase, ability to hydrolyse hippurate, sensitivity to nalidixic acid). ${ }^{26}$ At the beginning of this work, the clinical samples had been subcultivated three times and those from chickens twice. During transport to Sweden the strains were stored in Wilkins-Chalgren Transport Medium (Oxoid). Upon arrival, the strains were frozen at $-70^{\circ} \mathrm{C}$, as suspensions of bacteria harvested from blood agar plates, in Brain Heart Infusion Broth (Difco) supplemented with glycerol $15 \%$.

\section{Preparation of bacteria-free supernates}

The bacteria were inoculated from the frozen stock suspensions into 3-ml volumes of Hams' F10 cell culture medium supplemented with $5 \mathrm{~mm} \mathrm{~L}$-glutamine and cultivated at $42^{\circ} \mathrm{C}$ for $48 \mathrm{~h}$ in micro-aerophilic conditions in a GasPak system (BBL Microbiology Systems, Becton Dickinson and Co, Cockeysville, MD, USA) without a catalyst. The cultures were centrifuged for $30 \mathrm{~min}$ at $3000 \mathrm{~g}$. To eliminate bacteria still remaining in the supernates, these were either passed through cellulose filters (pore size $0.22 \mu \mathrm{m}$; Millipore Corp., Bedford, MA, USA), or gentamicin (Flow Laboratories, Irvine, Scotland) was added to a final concentration of $200 \mathrm{mg} / \mathrm{L}$. The bacteria-free supernates were then added within $3 \mathrm{~h}$ to the eukaryotic cells to be tested.

For preparation of polymyxin-treated supernates, polymyxin B sulphate (Sigma) $2 \mathrm{~g} / \mathrm{L}$ was added $10 \mathrm{~min}$ before ceasing cultivation.

An LT-producing $E$. coli strain (a clinical isolate from India, kindly provided by the National Bacteriological Laboratory, Stockholm, Sweden) was cultivated in $3 \mathrm{ml}$ of Hams' medium or Brain Heart Infusion broth at $37^{\circ} \mathrm{C}$ for $24 \mathrm{~h}$ in air, and the bacteriafree supernate was prepared as described above.

Rabbit antitoxin against human E. coli LT was kindly provided by Gunnel Sigstam, Karolinska Institute, Stockholm, Sweden. A dilution of 1 in 800 added simultaneously to $\mathrm{Y} 1$ cells with supernate from the LT-producing $E$. coli strain (diluted 1 in 10) neutralised the LT-induced cell rounding. $C$. difficile toxin B was purified as described previously. ${ }^{27}$

\section{Cultivation of cells}

Eagle's Minimal Essential Medium, Hams' F10 medium, bovine sera and trypsin were obtained from Flow Laboratories. MRC-5 cells were cultivated as previously described ${ }^{28}$ in Eagle's medium supplemented with newborn bovine serum $10 \%$. Vero cells were cultivated in Eagle's medium with fetal bovine serum $5 \%$, diploid Chinese hamster lung fibroblasts (Don) in Eagle's medium with fetal bovine serum $10 \%$. HeLa, Y1 and CHO cells were cultivated in Hams' medium with fetal bovine serum $10 \%$. All media were supplemented with $5 \mathrm{~mm}$ L-glutamine, penicillin $100000 \mathrm{U} / \mathrm{L}$ and streptomycin $10 \mathrm{mg} / \mathrm{L}$, and all cells were cultivated under the same conditions as the MRC- 5 cells. The cells were free of mycoplasma infection as determined by Hoechst staining ${ }^{29}$ and cultivation.

\section{Assay for enterotoxin}

Presence of enterotoxin was tested primarily in Y1 cells, ${ }^{30}$ to avoid confusion with the effect of the cytotoxin termed CLDT which is active in CHO cells but not in $\mathrm{Y} 1$ cells. ${ }^{25}$ The $\mathrm{Y} 1$ cells were seeded in 96well plates (A/S Nunc, Roskilde, Denmark) at $\left(5 \times 10^{5}\right)-\left(1 \times 10^{6}\right) /$ plate and cultivated for 5 days before testing. Confirmatory tests were performed in CHO cells. ${ }^{31}$ These cells were tested freshly seeded $\left(1 \times 10^{5}\right.$ cells/plate; $50 \mu \mathrm{l}$ of cell suspension/well), in medium without serum. For testing of the bacteria- 
free supernates, $200 \mu \mathrm{l}$ was added to each well with Y1 or $\mathrm{CHO}$ cells (the medium was first withdrawn from the Y1 cells). Enterotoxic effect was defined as rounding of Y1 cells (after 24 and $48 \mathrm{~h}$ ) and elongation of CHO cells (after 6 and $24 \mathrm{~h}$ ). Wells containing $\geqslant 50 \%$ of affected cells were considered to represent a positive result. As a positive control, supernate from the LTproducing E. coli strain, which induced rounding of Y1 cells and elongation of $\mathrm{CHO}$ cells, was used. The neutralising effect of antitoxin (diluted 1 in 400) against $E$. coli $\mathrm{LT}$ added simultaneously with supernate was tested for all samples that gave a positive result.

\section{Assay for cytotoxins}

Vero, MRC-5 and HeLa cells were seeded in 96-well plates with $1 \times 10^{5}, 1.5 \times 10^{5}$ and $3 \times 10^{5}$ cells/plate, respectively. ${ }^{28,32,33} \mathrm{HeLa}$ cells were cultivated for 2 days and the other cells for 5 days, to reach semiconfluency. The medium was removed, and $200 \mu \mathrm{l}$ of bacteria-free supernate was added to each well. Cytotoxic effects were assayed after 24 and $48 \mathrm{~h}$ by the presence of morphological changes in the cells. Wells containing $\geqslant 50 \%$ of affected cells were considered to be positive. $C$. difficile toxin B (inducing a cytotoxic effect in all mammalian cells ${ }^{34}$ ) was used as a positive control.

The cells from the enterotoxin and cytotoxin assays were observed in an inverted light microscope by two observers, each unaware of the results of the other. All tests were performed in duplicate and all strains were tested on three or four different occasions. Hams' medium (with $5 \mathrm{mM}$ L-glutamine) was used as a negative control.

To evaluate the effect of varying cell freshness and density, plates seeded with $2.5 \times 10^{4}$ and $5 \times 10^{4}$ cells and exposed to cytotoxin-containing supernate (undiluted and dilutions of 1 in 2, 4 and 10) after 2-3 days (when semi-confluent) were compared with plates seeded with $5 \times 10^{4}, 1 \times 10^{5}, 1.5 \times 10^{5}$, and $2 \times 10^{5}$ cells and tested immediately.

\section{Results}

\section{Production of enterotoxin}

Of 79 strains tested, a total of $33(42 \%)$ produced rounding of Y1 cells (table I). These comprised 16 $(62 \%)$ of the 26 strains from children with watery diarrhoea, $5(28 \%)$ of the 18 strains from children with bloody or inflammatory diarrhoea, and $12(34 \%)$ of the 35 strains from chickens. Four of the strains also produced cytotoxin.

The enterotoxic effect in the Y1 cells was often visible after $24 \mathrm{~h}$, but it developed maximally after $48 \mathrm{~h}$. After $72 \mathrm{~h}$ the effect was reversed, indicating that the enterotoxin was not cytolethal, in agreement with previous findings. ${ }^{25}$ The enterotoxic effect was inactivated by heating the supernate to $100^{\circ} \mathrm{C}$ for $10 \mathrm{~min}$. The rounding of $\mathrm{Y} 1$ cells was neutralised with antitoxin against $E$. coli LT in supernates from all 33 strains, indicating that the rounding was due to a specific enterotoxic activity. Confirmatory tests with CHO cells were also performed (data not shown). However, although the effect in CHO cells of the positive control E. coli LT was easily detected, these cells were clearly less sensitive than $\mathrm{Y} 1$ cells to campylobacter enterotoxin.

After storage of the strains for 1 year at $-70^{\circ} \mathrm{C}$, the production of enterotoxin was tested in 23 strains and found to be lost (or decreased to hardly detectable amounts) in all strains tested.

\section{Production of cytotoxins}

Of 79 strains tested, a total of $8(10 \%)$ strains produced a specific cytotoxic effect in MRC-5, Vero and $\mathrm{HeLa}$ cells after $24 \mathrm{~h}$ (table I): $2(11 \%)$ of 18 strains-from children with bloody or inflammatory diarrhoea, and $6(17 \%)$ of the 35 strains from chickens. Four of these strains also produced enterotoxin. The isolate from chickens that gave the highest cytotoxic effect caused haemorrhage in a rabbit ileal loop ${ }^{35}$ (data not shown).

The appearance of the morphological response was the same in all three cell types tested with all of the eight cytotoxin-positive strains (fig. 1). After $24 \mathrm{~h}$, the cells had rounded up and looked wrinkled and shrunken. After a few days the cells degenerated, indicating that the cytotoxic effect was lethal. The cytotoxic effect was inactivated by heating the supernate to $100^{\circ} \mathrm{C}$ for $10 \mathrm{~min}$.

Polymyxin has been reported to increase the yield of toxin in some reports and to be without effect in others. $^{5,6,15,18,20}$ The titres of our supernates were not

Table I. Frequencies of enterotoxin (ET) and cytotoxin (CT) production in $C$. jejuni strains isolated from children with diarrhoea and from chickens

\begin{tabular}{l|cccc}
\hline \multirow{2}{*}{$\begin{array}{c}\text { Source of } \\
\text { Campylobacter } \\
\text { strains (number) }\end{array}$} & \multicolumn{4}{c}{ Number (\%) of strains that were } \\
\cline { 2 - 5 } & ET $^{-}$CT $^{-}$ & ET $^{+}$CT $^{-}$ & ET $^{-}$CT $^{+}$ & ET $^{+}$CT $^{+}$ \\
\hline Children with diarrhoea (44) & $22(50)$ & $20(45)$ & $1(2)$ & $1(2)$ \\
watery (26) & $10(38)$ & $16(62)$ & 0 & 0 \\
bloody or inflammatory (18) & $12(67)$ & $4(22)$ & $1(5 \cdot 5)$ & $1(5 \cdot 5)$ \\
Chickens (35) & $20(57)$ & $9(26)$ & $3(8 \cdot 5)$ & $3(8 \cdot 5)$ \\
Total (79) & $42(53)$ & $29(37)$ & $4(5)$ & $4(5)$ \\
\hline
\end{tabular}



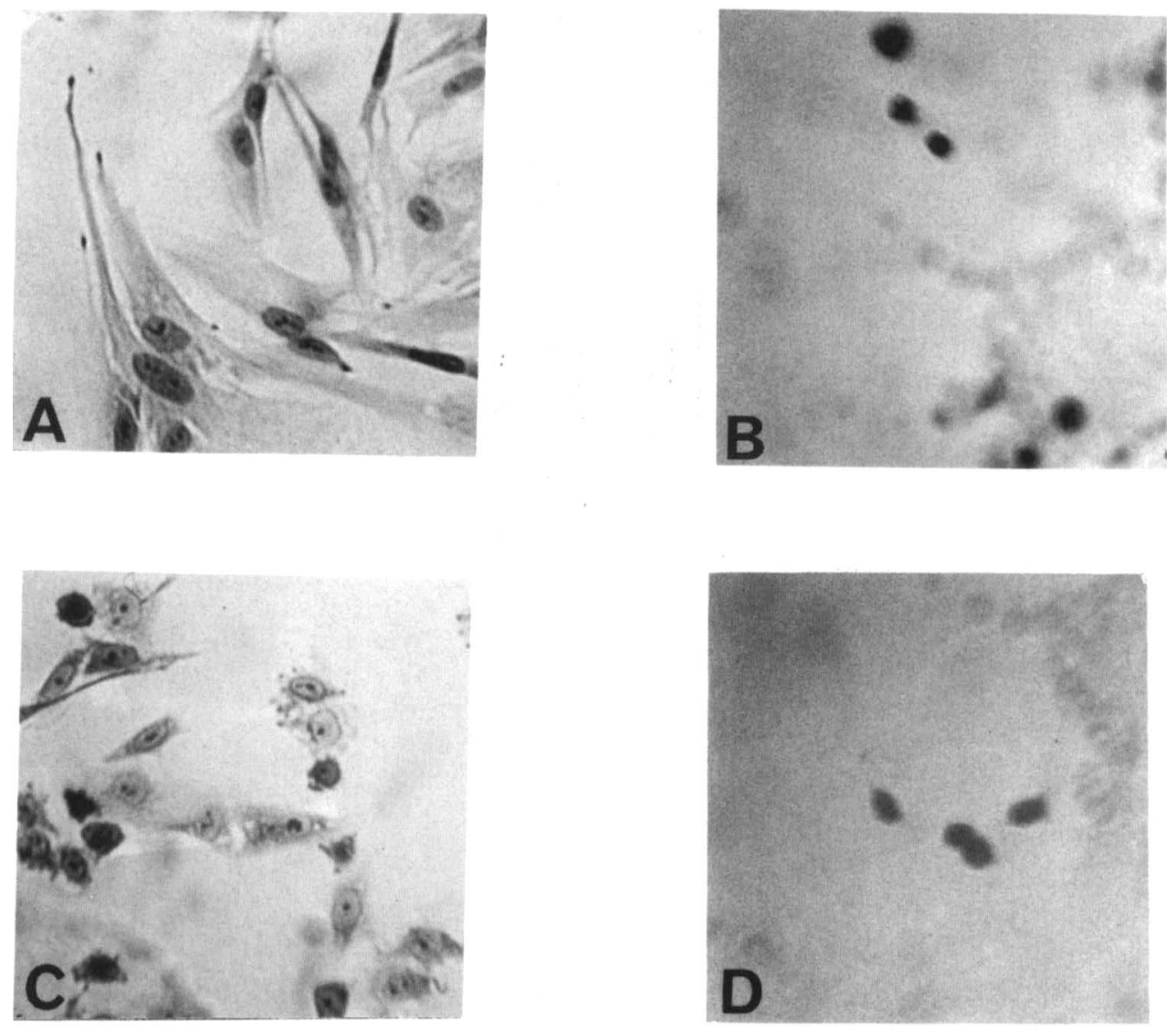

Fig. 1. Untreated cells $(A, C)$ and cells treated with supernate from C. jejuni (B, D). A, B, MRC-5 cells; C, D, HeLa cells. The cells were stained by Giemsa's stain. Magnification $\times 400$.

increased by addition of polymyxin $\mathbf{B}$. The production of cytotoxin was lost (or decreased to hardly detectable amounts) in all cytotoxin-positive strains after storage for 1 year at $-70^{\circ} \mathrm{C}$.

\section{Characteristics of the cytotoxic effect}

The effect of varying cell freshness and density in the assay for cytotoxin was evaluated with the two cytotoxin-positive clinical isolates. MRC-5, Don, HeLa and Vero cells were studied in parallel (table II). The results were similar for both isolates and are shown in table II for the one that produced slightly more cytotoxin and did not also produce enterotoxin.

The cytotoxic effect was more prominent in freshly seeded cells (table II) than in semi-confluent monolayers. Addition of toxin-containing supernate to freshly seeded cells prevents their outgrowth, which could be detected after $24 \mathrm{~h}$ when the control cells had attached and started to grow but the toxin-treated cells still were rounded. When the cells had grown to semiconfluency before addition of supernate, a rounding up of the cells was observed, but only in wells with low cell density. With higher cell density the cells stopped dividing but did not round up; 2-3 days further growth of the untreated control cells were required to detect this effect.

With freshly seeded cells, the dilution of supernate that gave a cytotoxic effect in $\geqslant 50 \%$ of cells varied from 1 in 10 to not detectable in undiluted supernate (but demonstrable in concentrated supernate), when comparing the different cell types at different cell densities (table II). The fibroblasts were generally more sensitive than the epithelial cells. Of the fibroblasts, Don cells were more sensitive than MRC-5 (fig. 1 A, B), and of the epithelial cells, Vero cells were more sensitive than HeLa cells (fig. 1C, D). As expected, the cytotoxic effect was less pronounced with higher cell densities. With lower cell densities the variations in response between the different cell types were less than with higher densities. The variations in response as a function of different cell densities were less in Don and Vero cells than in MRC-5 and HeLa cells (table II).

When testing the supernates after storage at $4^{\circ} \mathrm{C}$ for 1 week, results relating to differences between cell types and densities were similar to those obtained with supernates tested directly after preparation, although the dilution inducing a cytotoxic effect in $50 \%$ of cells was usually decreased by a factor of two (table II).

Cytotoxin-positive supernates induced a toxic effect also in $\mathrm{CHO}$ and $\mathrm{Y} 1$ cells. These cells were significantly less sensitive than the other cells tested. A cytotoxic effect was detectable only with freshly seeded cells. As with the other cells tested, these cells remained rounded and never grew out. 
Table II. Comparison of the sensitivity of freshly seeded MRC-5, Don, Vero and HeLa cells at different cell densities to the cytotoxic effect of supernates from a cytotoxin-positive, enterotoxin-negative $C$. jejuni isolate

\begin{tabular}{|c|c|c|c|c|c|c|c|c|c|c|}
\hline \multirow{3}{*}{$\begin{array}{l}\text { Cell type and number } \\
\text { of cells }\left(10^{3}\right) / \text { plate }\end{array}$} & \multicolumn{5}{|c|}{ Freshly prepared supernate } & \multicolumn{5}{|c|}{$\begin{array}{l}\text { Supernate added to cells prepared } \\
1 \text { week previously and held at } 4^{\circ} \mathrm{C}\end{array}$} \\
\hline & \multicolumn{4}{|c|}{$\begin{array}{l}\text { Percentage CPE } \\
\text { with dilution } \\
\text { factor of }\end{array}$} & \multirow[t]{2}{*}{$\begin{array}{c}\text { Dilution } \\
\text { inducing } \\
\geqslant 50 \% \text { CPE }\end{array}$} & \multicolumn{4}{|c|}{$\begin{array}{l}\text { Percentage CPE } \\
\text { with dilution } \\
\text { factor of }\end{array}$} & \multirow[t]{2}{*}{$\begin{array}{c}\text { Dilution } \\
\text { inducing } \\
\geqslant 50 \% \mathrm{CPE}\end{array}$} \\
\hline & undiluted & 2 & 4 & 10 & & undiluted & 2 & 4 & 10 & \\
\hline \multicolumn{11}{|l|}{ MRC-5 } \\
\hline 50 & 100 & 100 & 100 & 100 & $\geqslant 10$ & 100 & 100 & 100 & 100 & $\geqslant 10$ \\
\hline 100 & 100 & 100 & 70 & 70 & $\geqslant 10$ & 100 & 50 & 20 & 0 & 2 \\
\hline 150 & 100 & 80 & 40 & 20 & 2 & 100 & 50 & 80 & 0 & 4 \\
\hline 200 & 100 & 60 & 40 & 20 & 2 & 100 & 50 & 80 & 0 & 4 \\
\hline \multicolumn{11}{|l|}{ Don } \\
\hline 50 & 100 & 100 & 80 & 80 & $\geqslant 10$ & 100 & 100 & 80 & 50 & 10 \\
\hline 100 & 100 & 80 & 80 & 60 & $\geqslant 10$ & 100 & 80 & 80 & 50 & 10 \\
\hline 150 & 100 & 80 & 70 & 70 & $\geqslant 10$ & 100 & 70 & 60 & 60 & 10 \\
\hline 200 & 100 & 80 & 60 & 60 & $\geqslant 10$ & 100 & 70 & 60 & 60 & 10 \\
\hline \multicolumn{11}{|l|}{ Vero } \\
\hline 50 & 100 & 100 & 100 & 0 & 4 & 100 & 100 & 0 & 0 & 2 \\
\hline 100 & 100 & 100 & 60 & 0 & 4 & 100 & 90 & 0 & 0 & 2 \\
\hline 150 & 100 & 80 & 80 & 0 & 4 & 100 & 80 & 0 & 0 & 2 \\
\hline 200 & 100 & 80 & 60 & 0 & 4 & 90 & 60 & 0 & 0 & 2 \\
\hline \multicolumn{11}{|l|}{ HeLa } \\
\hline 50 & 100 & 50 & 50 & 0 & 4 & 100 & 50 & 0 & 0 & 2 \\
\hline 100 & 50 & 0 & 0 & 0 & undiluted & 50 & 0 & 0 & 0 & undiluted \\
\hline 150 & 30 & 0 & 0 & 0 & undiluted & 30 & 0 & 0 & 0 & undiluted \\
\hline 200 & 30 & 0 & 0 & 0 & undiluted & 30 & 0 & 0 & 0 & undiluted \\
\hline
\end{tabular}

Percentage CPE was scored after cells had been exposed to supernate for 3 days.

\section{Discussion}

In this study we have determined the frequencies of enterotoxin and cytotoxin production in $C$. jejuni strains isolated in Costa Rica from children with diarrhoea and from chickens, and compared our data with the incidence of toxigenic Campylobacter strains in other countries. This type of knowledge is important both epidemiologically and clinically, because the significance of these toxins in the pathogenesis is still not clearly established.

Infections with Campylobacter spp. can present with various symptoms, ranging from watery diarrhoea, which is the most frequent symptom in developing countries, to a dysentery-like syndrome with an inflammatory response in the bowel, which is more common in the industrialised world. ${ }^{1}$ It has been suggested that, by analogy with $E$. coli, the watery diarrhoea is caused by the enterotoxin, and the inflammatory response by one or more of the cytotoxins. Such a correlation between different manifestations of the disease and the presence of enterotoxin and cytotoxin was presented in one study..$^{19}$

In our study, we found production of enterotoxin in $62 \%$ of strains from children with watery diarrhoea and in $28 \%$ of strains from children with bloody or inflammatory diarrhoea. In other reports, the incidence of enterotoxigenic strains from children with watery diarrhoea varied between $32 \%$ in Southern India, ${ }^{36} 75 \%$ in Mexico ${ }^{4}$ and Algeria, ${ }^{37}$ and $100 \%$ in Belgium. ${ }^{38}$ The frequency of enterotoxin-producing strains from patients with inflammatory diarrhoea ranged from $0 \%$ in the $\mathrm{USA}^{39}$ to $100 \%$ in Belgium. ${ }^{38}$

Several possible explanations for these large discrepancies in frequencies have been proposed: (i) the production of toxin is lost during subcultivation or storage of the strains before testing; (ii) the yield of toxin is influenced by different cultivation media and conditions for preparation of toxin; and (iii) the amount of toxin detected is influenced by different detection systems. It has also been claimed that the frequency of enterotoxin production has been overestimated, because the enterotoxic effect, as detected in $\mathrm{CHO}$ cells, may be confused with the effect of one of the cytotoxins (CLDT). ${ }^{25}$ These authors obtained a frequency of enterotoxin production as low as $10 \%$. However, we found an enterotoxin frequency of $62 \%$, and this is not an overestimation because we used $\mathrm{Y} 1$ cells and the effect was neutralised with antitoxin against $E$. coli LT. Moreover, in several of the other reports referred to above, the effects of the enterotoxin were tested in Y1 cells or neutralised with antitoxin, or both. The different frequencies reported may also have another explanation: the gene for toxin production may normally be repressed, and activated only during certain conditions. This is suggested by the following observations: (i) by increasing the concentration of iron, production of enterotoxin was detected in strains which were previously negative for toxin $;^{\mathbf{4 0}}$ (ii) non-producing strains were converted to enterotoxin-producers after passage through the gut of a rat. ${ }^{41}$ In this context, a cholera toxin gene probe 
was found recently to hybridise also with DNA from non-toxigenic strains. ${ }^{42}$ Thus, most probably all $\mathrm{Cam}$ pylobacter strains are potential producers of the enterotoxin. This hypothesis is consistent with the observation that watery diarrhoea is associated with the enterotoxin and inflammatory diarrhoea with the cytotoxin(s). Most probably, watery diarrhoea is the consequence when only enterotoxin is produced, whereas inflammatory diarrhoea is due to a combined effect of the enterotoxin and one (or several) of the cytotoxins.

Cytotoxin-producing strains were not found in children with watery diarrhoea but represented $11 \%$ of strains from children with bloody or inflammatory diarrhoea. Studies of the production of cytotoxin in Campylobacter spp. have not been as frequent as those on enterotoxin production. We have not found any other study concerning cytotoxin-producing Campylobacter spp. in children. However, in two studies from the USA, $42 \%$ and $32 \%$ of the strains from adults with inflammatory diarrhoea produced cytotoxin. ${ }^{15,39}$ In other studies concerning cytotoxins in isolates from adults, in which the type of diarrhoea was not specified, the frequencies varied from $18 \%$ to $84 \% .^{11,13,18,20,23}$ The same explanations proposed for the different frequencies reported for the enterotoxin are appropriate for the cytotoxin(s). However, the different frequencies reported might also refer to different toxins. These facts make it difficult to draw any definite conclusions about the correlation between cytotoxin production and type of disease. When optimal conditions for detection of the different cytotoxins are established, all strains from patients with an inflammatory response will probably be found to produce one or several cytotoxins. Nevertheless, it seems reasonable to assume that, in contrast to the enterotoxin, cytotoxin(s) are not generally produced by all Campylobacter strains, since all patients do not show an inflammatory response.

The cytotoxin observed in our study is most probably identical with the one active in Vero cells first described by Johnson and Lior ${ }^{17}$ and Klipstein et al. ${ }^{19}$ As well as the finding that our cytotoxin is active in Vero cells, there are other similarities between our study and other studies concerning this cytotoxin: (i) the morphological response in our cells is closely similar to the ones previously shown $;{ }^{17,20}$ (ii) as in our study, the cells were tested when freshly seeded ${ }^{19}$ or within $36 \mathrm{~h}$ of seeding $;^{18}$ (iii) Vero cells were slightly more sensitive than HeLa cells ${ }^{18}$ (except in one study ${ }^{19}$ in which HeLa cells were found to be more sensitive than Vero cells, but the authors assumed that this was due to the fact that different number of cells were tested); (iv) the maximum dilution inducing a cytotoxic effect was 1 in $4,{ }^{18}$ and in one study supernates concentrated 10 -fold were used. ${ }^{19}$ The stability of the Vero-active toxin at $4^{\circ} \mathrm{C}$ (table II) has not been studied before, but seemed to correspond well with the stability found for the cytotoxin which is not active in Vero cells. ${ }^{15}$ Purification and characterisation of our cyto- toxin are in progress. In preliminary experiments, the toxin eluting from a Mono Q-column (FPLC) gave a major band at $c .100 \mathrm{kDa}$ in a sodium dodecylsulphate gel (Gené and Antillon, unpublished results).

In this study, the same type of cytotoxin was found in all cytotoxin-positive strains. The same is true for other studies; all strains in every study produce either the Vero-active toxin or the other one, which is not active in Vero cells (the presence of CLDT has only been reported once). This is probably not a consequence of different toxins being elaborated in different parts of the world, since the Vero-active toxin has been detected in the USA, ${ }^{15,19}$ Canada,${ }^{17}$ Bangladesh ${ }^{20}$ and now in Costa Rica, and the other toxin in USA, ${ }^{15}$ $\mathrm{UK}^{13}$ and Malaysia. ${ }^{11}$ We have been able to detect neither similarities in choice of cultivation media nor in method for preparation of the toxins between studies dealing with the Vero-active toxin, in contrast with studies dealing with the other cytotoxin. Possibly, the reason for this will be clarified when the existence of several different cytotoxins is more widely acknowledged and their nature is more clearly understood.

Chickens are the commonest reservoir of $C$. jejuni $i^{43}$ and are generally colonised without signs of disease. ${ }^{44}$ We have shown that $34 \%$ of Campylobacter strains isolated from refrigerated chickens available for consumption in local stores in Costa Rica produced enterotoxin. This agrees well with an isolation rate of $31 \%$ in India ${ }^{41}$ and $39 \%$ in Sweden ${ }^{45}$, although in the UK only a $6 \%$ carriage rate was detected ${ }^{13}$ and in Pakistan and Mexico $87 \%$ and $100 \%$, respectively. ${ }^{45}$ We found that $17 \%$ of the strains from chickens produced cytotoxin, compared with $16 \%$ in the UK (toxin not active in Vero cells) ${ }^{13}$ and $33 \%$ in Bangladesh (Vero-active toxin). ${ }^{20}$ We have confirmed the findings from Bangladesh ${ }^{20}$ of a cytotoxin active against $\mathrm{HeLa}$ and Vero cells, and substantiated their findings by showing that this cytotoxin is active also in fibroblasts, as well as in $\mathrm{CHO}$ and $\mathrm{Y} 1$ cells when tested freshly seeded. Furthermore, we have tested the presence of enterotoxin in the same strains and found co-production in three of them. Few other studies report the simultaneous production of both toxins in C. jejuni. ${ }^{18,23}$ In these, both toxins were found in about $50 \%$ of strains. In total we have found four strains that produce both enterotoxin and cytotoxin.

It has been suggested that these toxins do not have any role in the pathogenesis of campylobacter-induced infections, since the titres are low, usually $2-8$ for the cytotoxins and up to 64 for the enterotoxin. Some authors point out that it is necessary to concentrate the supernate 5-50 fold to detect a toxic effect at all, ${ }^{19}$ or that unconcentrated supernates are able to induce an effect only in freshly seeded cells. ${ }^{5}$ We used the same approach to this problem as Johnson and Lior, ${ }^{18}$ who cultivated the strains in cell culture medium, which then was added undiluted to the test cells. In this way, it was possible to test the supernates undiluted, in contrast to the cases when the strains were grown in 
bacterial cultivation media which cannot be added undiluted to eukaryotic cells without toxic effects. Although the toxins are produced in limited amounts in vitro, these amounts are comparable to the amounts of certain toxins produced by $E$. coli. ${ }^{21}$ The amounts produced in vivo might of course be larger, especially in the light of the reported stimulation of toxin-production after gut passage. ${ }^{41}$ The most important aspect is thus the capability of a strain to produce toxin, not the amount of toxin detected in vitro.

In future studies to detect cytotoxins produced by Campylobacter spp., at least two different cell types should be used, of which one should be Vero cells and the other could be HeLa cells but, preferably, a fibroblast line, since these are more sensitive. It would be best to test cells at low densities (freshly trypsinised

\section{References}

1. Walker RI, Caldwell MB, Lee EC, Guerry P, Trust TJ, RuizPalacios GM. Pathophysiology of Campylobacter enteritis. Microbiol Rev 1986; 50: 81-94.

2. Mata L, Simhon A, Padilla R et al. Diarrhea associated with rotaviruses, enterotoxigenic Escherichia coli, Campylobacter, and other agents in Costa Rican children, 1976-1981. Am J Trop Med Hyg 1983; 32: 146-153.

3. Rivera P, Hernandez F, Rodriguez R, Herrera ML. Observations concerning epidemiology of infections with Campylobacter fetus spp jejuni. Rev Méd Hosp Nal Ninos Costa Rica 1983; 18: 21-29.

4. Ruiz-Palacios GM, Torres J; Torres NI, Escamilla E, RuizPalacios BR, Tamayo J. Cholera-like enterotoxin produced by Campylobacter jejuni. Characterisation and clinical significance. Lancet 1983; 2: 250-253.

5. McCardell BA, Madden JM, Lee EC. Production of choleralike toxin by Campylobacter jejuni/coli. Lancet 1984; 1 : 448-449.

6. Klipstein FA, Engert RF. Properties of crude Campylobacter jejuni heat-labile enterotoxin. Infect Immun 1984; 45 314-319

7. Klipstein FA, Engert RF. Immunological relationship of the B subunits of Campylobacter jejuni and Escherichia coli heatlabile enterotoxins. Infect Immun 1985; 48: 629-633.

8. McCardell BA, Madden JM, Stanfield JT. Purification of Campylobacter cytotonic toxin by fast protein liquid chromatography. In: Kaijser B, Falsen E (eds) Campylobacter IV. Goterna, Kungälv. 1988: 233.

9. Torres J, Lindblom G-B, Lönnroth I, Kaijser B. Studies on a partial purified enterotoxin from C. jejuni. In: Kaijser B, Falsen E (eds) Campylobacter IV. Goterna, Kungälv. 1988: 243.

10. Daikoku T, Kawaguchi M, Takama K, Suzuki S. Partial purification and characterization of the enterotoxin produced by Campylobacter jejuni. Infect Immun 1990; 58 2414-2419.

11. Wong P Yeen, Puthucheary SD, Pang T. Demonstration of a cytotoxin from Campylobacter jejuni. J Clin Pathol 1983; 36: $1237-1240$.

12. Pang T, Wong PY, Puthucheary SD, Sihotang K, Chang WK. In-vitro and in-vivo studies of a cytotoxin from Campylobacter jejuni. J Med Microbiol 1987; 23: 193-198.

13. Fricker CR, Park RWA. A two-year study of the distribution of 'thermophilic' campylobacters in human, environmental and food samples from the Reading area with particular reference to toxin production and heat-stable serotype. $J$ Appl Bacteriol 1989; 66: 477-490.

14. Goossens H, Rummens E, Cadranel S, Butzler J-P, Takeda Y. Cytotoxic activity on Chinese hamster ovary cells in culture filtrates of Campylobacter jejuni/coli. Lancet 1985; 2: 511.

15. Guerrant RL, Wanke CA, Pennie RA, Barrett LJ, Lima AAM, O'Brien AD. Production of a unique cytotoxin by Campylobacter jejuni. Infect Immun 1987; 55: 2526-2530. or within a few days after seeding), and to test the supernates immediately after preparation, preferably after a concentration step. Johnson and Lior ${ }^{25}$ recommended testing for cytotoxins in monolayer cultures in order not to confuse the effect with that of CLDT, which affects only cultures with a low cell number. However, since other cytotoxins present in low amounts may be missed with this approach, we recommend that tests for the presence of all cytotoxins are done in freshly seeded cells. The completely different morphological effect of CLDT will help in distinguishing the toxins.

We thank B. Gustafsson, J. A. Gené and M. Thelestam for stimulating discussions. This study was supported by the foundations of Anders Otto Svärd and Torsten and Ragnar Söderberg.

16. Mahajan S, Rodgers FG. Isolation, characterization, and hostcell-binding properties of a cytotoxin from Campylobacter jejuni. J Clin Microbiol 1990; 28: 1314-1320.

17. Johnson WM, Lior H. Toxins produced by Campylobacter jejuni and Campylobacter coli. Lancet 1984; 1 : 229-230.

18. Johnson WM, Lior H. Cytotoxic and cytotonic factors produced by Campylobacter jejuni, Campylobacter coli, and Campylobacter laridis. J Clin Microbiol 1986; 24: 275-281.

19. Klipstein FA, Engert RF, Short H, Schenk EA. Pathogenic properties of Campylobacter jejuni: assay and correlation with clinical manifestations. Infect Immun 1985; 50 : 43-49.

20. Akhtar SQ, Huq F. Effect of Campylobacter jejuni extracts and culture supernatants on cell culture. J Trop Med Hyg 1989; 92: $80-85$.

21. Moore MA, Blaser MJ, Perez-Perez GI, O'Brien AD. Production of a Shiga-like cytotoxin by Campylobacter. Microb Pathog 1988; 4: 455-462.

22. O'Brien AD, Holmes RK. Shiga and Shiga-like toxins. Microbiol Rev 1987; 51: 206-220.

23. Daikoku T, Suzuki S, Oka S, Takama K. Profiles of enterotoxin and cytotoxin production in Campylobacter jejuni and C. coli. FEMS Microbiol Lett 1989; 58: 33-36.

24. McCardell BA, Madden JM, Stanfield JT. Production of cytotoxins by Campylobacter. Lancet 1986; 1: 1031 .

25. Johnson WM, Lior $\mathbf{H}$. A new heat-labile cytolethal distending toxin (CLDT) produced by Campylobacter spp. Microb Pathog 1988; 4: 115-126.

26. Antillon F, Odio E, Garcia V. Presence of Campylobacter jejuni, $C$. coli and $C$. laridis in fresh chickens from the metropolitan area of San José. Costa Rica Rev Cost Cienc Méd 1987; 8: 39-41.

27. Florin I, Thelestam M. Internalization of Clostridium difficile cytotoxin into cultured human lung fibroblasts. Biochim Biophys Acta 1983; 763 : 383-392.

28. Florin I, Thelestam M. Intoxication of cultured human lung fibroblasts with Clostridium difficile toxin. Infect Immun $1981 ; 33: 67-74$.

29. Chen TR. In situ detection of mycoplasma contamination in cel cultures by fluorescent Hoechst 33258 stain. Exp Cell Res 1977; 104: 255-262.

30. Donta ST, Moon HW, Whipp SC. Detection of heat-labile Escherichia coli enterotoxin with the use of adrenal cells in tissue culture. Science 1974; 183: 334-336.

31. Guerrant RL, Brunton LL, Schnaitman TC, Rebhun L, Gilman AG. Cyclic adenosine monophosphate and alteration of Chinese hamster ovary cell morphology: a rapid, sensitive in vitro assay for the enterotoxins of Vibrio cholerae and Escherichia coli. Infect Immun 1974; 10: 320-327.

32. Konowalchuk J, Speirs JI, Stavric S. Vero response to a cytotoxin of Escherichia coli. Infect Immun 1977; 18 775-779.

33. Gentry MK, Dalrymple JM. Quantitative microtiter cytotoxicity assay for Shigella toxin. J Clin Microbiol 1980;12 361-366.

34. Thelestam M, Florin, I. Interaction of Clostridium difficile toxin 
B (cytotoxin) with cultured cells. In: Borriello S P (ed) Antibiotic-associated diarrhoea and colitis. The role of Clostridium difficile in gastrointestinal disorders. (Developments in gastroenterology 5) Hague, Martinus Nijhoff Publishers. 1984: 103-118.

35. Evans DG, Evans DJ, Pierce NF. Differences in the response of rabbit small intestine to heat-labile and heat-stable enterotoxins of Escherichia coli. Infect Immun 1973; 7: 873-880.

36. Mathan VI, Rajan DP, Klipstein FA, Engert RF. Enterotoxigenic Campylobacter jejuni among children in South India. Lancet 1984; 2 : 981.

37. Belbouri A, Mégraud F. Enterotoxin-like activity produced by Campylobacter jejuni and Campylobacter coli isolated from patients and healthy controls in Algeria. FEMS Microbiol Lett 1988; 51: 25-28.

38. Goossens H, Butzler J-P, Takeda Y. Demonstration of choleralike enterotoxin production by Campylobacter jejuni. FEMS Microbiol Lett 1985; 29: 73-76.

39. Perez-Perez GI, Cohn DL, Guerrant RL, Patton CM, Barth Reller L, Blaser MJ. Clinical and immunologic significance of cholera-like toxin and cytotoxin production by Campylobacter species in patients with acute inflammatory diarrhea in the USA. $J$ Infect Dis $1989 ; 160: 460-468$.
40. McCardell BA, Madden JM, Stanfield JT. Effect of iron concentration on toxin production in Campylobacter jejuni and Campylobacter coli. Can J Microbiol 1986; 32: 395-401.

41. Saha SK, Singh NP, Sanyal SC. Enterotoxigenicity of chicken isolates of Campylobacter jejuni in ligated ileal loops of rats. J Med Microbiol 1988; 26: 87-91.

42. Calva E, Torres J, Vazquez M, Angeles V, de la Vega H, RuizPalacios GM. Campylobacter jejuni chromosomal sequences that hybridize to Vibrio cholerae and Escherichia coli LT enterotoxin genes. Gene 1989; 75: 243-251.

43. Harris NV, Weiss NS, Nolan CM. The role of poultry and meats in the etiology of Campylobacter jejuni/coli enteritis. Am J Public Health 1986; 76: 407-411.

44. Lindblom G-B, Kaijser B, Sjögren E. Enterotoxin production and serogroups of Campylobacter jejuni and Campylobacter coli from patients with diarrhea and from healthy laying hens. J Clin Microbiol 1989; 27: 1272-1276.

45. Lindblom G-B, Johny M, Khalil K, Mazhar K, Ruiz-Palacios GM, Kaijser B. Enterotoxigenicity and frequency of Campylobacter jejuni, C. coli and C. laridis in human and animal stool isolates from different countries. FEMS Microbiol Lett 1990; 66: 163-168. 